\title{
Phototaxis and polarotaxis hand in hand: Night dispersal flight of aquatic \\ insects distracted synergistically by light intensity and reflection polarization
}

Pál Boda $^{1 *}$, Gábor Horváth ${ }^{2}$, György Kriska ${ }^{3,4}$, Miklós Blahó ${ }^{2}$ and Zoltán Csabai ${ }^{5}$

${ }^{1}$ Department of Tisza River Research, MTA Centre for Ecological Research,

Bem tér 18/c, H-4026 Debrecen, Hungary

${ }^{2}$ Environmental Optics Laboratory, Department of Biological Physics, Physical Institute,

Eötvös University, H-1117 Budapest, Pázmány sétány 1, Hungary

${ }^{3}$ Group for Methodology of Biology Teaching, Biological Institute, Eötvös University,

H-1117 Budapest, Pázmány sétány 1, Hungary

${ }^{4}$ Danube Research Institute, MTA Centre for Ecological Research,

Alkotmány út 2-4, H-2163 Vácrátót, Hungary

${ }^{5}$ Department of Hydrobiology, Institute of Biology, Faculty of Sciences, University of Pécs,

Ifjúság útja 6, H-7624 Pécs, Hungary

* corresponding author, e-mail address: boda.pal@okologia.mta.hu

Running Head: Phototaxis and Polarotaxis Hand in Hand

\section{Megjelenési adatok:}

Pál Boda, Gábor Horváth, György Kriska, Miklós Blahó, Zoltán Csaba (2014) Phototaxis and polarotaxis hand in hand: night dispersal flight of aquatic insects distracted synergistically by light intensity and reflection polarization. - Naturwissenschaften 101: 385-395.

DOI 10.1007/s00114-014-1166-2

http://link.springer.com/article/10.1007\%2Fs00114-014-1166-2 


\begin{abstract}
Based on an earlier observation in the field, we hypothesized that light intensity and horizontally polarized reflected light may strongly influence the flight behaviour of night-active aquatic insects. We assumed that phototaxis and polarotaxis together have a more harmful effect on the dispersal flight of these insects than they would have separately. We tested this hypothesis in a multiplechoice field experiment using horizontal test surfaces laid on the ground. We offered simultaneously the following visual stimuli for aerial aquatic insects: (1) lamplit matte black canvas inducing phototaxis alone, (2) unlit shiny black plastic sheet eliciting polarotaxis alone, (3) lamplit shiny black plastic sheet inducing simultaneously phototaxis and polarotaxis, and (4) unlit matte black canvas as a visually unattractive control. The unlit matte black canvas trapped only a negligible number (13) of water insects. The sum (16432) of the total numbers of water beetles and bugs captured on the lamplit matte black canvas (7922) and the unlit shiny black plastic sheet (8510) was much smaller than the total catch (29682) caught on the lamplit shiny black plastic sheet. This provides experimental evidence for the synergistic interaction of phototaxis (elicited by the unpolarized direct lamplight) and polarotaxis (induced by the strongly and horizontally polarized plastic-reflected light) in the investigated aquatic insects. Thus, horizontally polarizing artificial lamplit surfaces can function as an effective ecological trap due to this synergism of optical cues, especially in the urban environment.
\end{abstract}

Key words: ecological trap, visual ecology, photopollution, polarized light pollution, phototaxis, polarotaxis, cue synergism 


\section{Introduction}

The majority of aquatic insects must disperse among water bodies to optimize their reproductive efforts and maximize their survival efficacy (Bilton et al. 2011). The dispersal flight behaviour is driven and influenced by biotic (e.g. Boda and Csabai 2009; Yee et al. 2009) and abiotic (e.g. Weigelhofer et al. 1992) interacting factors resulting in well-defined seasonal and diel dispersal patterns of aquatic insects (Csabai et al. 2006, 2012; Boda and Csabai 2013). The regular dispersal flight of aquatic insects can be seriously distracted by various man-made objects (Kriska et al. 2006, 2008; Horváth et al. 2007; Málnás et al. 2011).

Many of the dusk-active (crepuscular) or night-active (nocturnal) aquatic insect species possess positive phototaxis, that is they are attracted to the intensity of unpolarized light of given spectral characteristics. It has long been observed that artificial lighting influences the flight behaviour of aquatic insects as they are lured to light (Nowinszky 2003, Choi et al. 2009). This effect is used in light traps being a classical tool of mass sampling in insect ecology (Nowinszky 2004). Numerous different human-made light sources significantly decrease the probability of successful animal dispersal in nature (Frank 2006). Artificial light can trigger abnormal dispersal behaviour such as abnormal or disorientation (Longcore and Rich 2004).

Primary water insects (the larvae and adults of which live in water; e.g. water beetles and bugs) and secondary aquatic insects (the larvae of which develop in water, but the adults are terrestrial; e.g. dragonflies, tabanid flies, caddisflies, non-biting midges, mayflies, stoneflies) possess also positive polarotaxis, that is, they are attracted to horizontally polarized light, because they find water by means of the horizontal polarization of water-reflected light (Schwind 1991; Kriska et al. 1998; Wildermuth 1998; Bernáth et al. 2002; Horváth et al. 2008; Lerner et al. 2008; Boda and Csabai 2013). Strongly and horizontally polarizing artificial surfaces (e.g. asphalt roads, oil lakes, black plastic sheets used in agriculture, shiny dark-coloured cars, solar panels and 
collectors) - mimicking the reflection-polarization characteristics of water surfaces - may confuse flying, water-seeking polarotactic water insects. These man-made polarizing reflecting surfaces cause daylong polarized light pollution, that has disastrous consequences for polarotactic insects (Horváth and Zeil 1996; Kriska et al. 2006; Bernáth et al. 2001; Horváth et al. 2009, 2010a,b).

Water-seeking aquatic insects are lured to such polarizing surfaces, land onto them and try to swim. If the surface is hot, the smaller insects die within a few seconds due to dehydration. If the surface is cooler, the landed insects fly away (within 5-15 minutes after many unsuccessful attempts) to find an appropriate habitat. The females of many aquatic insect species (e.g. Ephemeroptera and Odonata) have been observed to lay eggs onto polarized-light-polluting surfaces (Kriska et al. 1998; Horváth et al. 2007). These eggs inevitably perish due to dehydration. Such artificial surfaces can also cozen the males: male dragonflies were reported to exhibit territorial behaviour above shiny car bonnets or black gravestones, like at their natural reproductive sites (Wildermuth and Horváth 2005; Horváth et al. 2007). This type of ecological trap can substantially reduce the fitness and reproductive success of aquatic insects (Horváth et al. 2009).

Both kinds of light pollution, photopollution (Longcore and Rich 2004) and polarized light pollution (Horváth et al. 2009) have substantial and harmful effects on aquatic insects separately. However, these two phenomena can also occur simultaneously in nature (e.g. asphalt roads with public lighting, or artificially lit glass buildings). In Hungary, near lake Balaton, Horváth et al. (2010a) found Hydrophilus piceus water beetles landed on a strongly and horizontally polarizing lamplit dry asphalt road, while they never found any such beetle on the lamplit soil outside the asphalt surface. The lively beetles moved continuously on the asphalt and did not leave its circular lamplit area. When they reached the dim boundary of the light patch, they returned to the opposite direction, thus they always stayed in the horizontally polarizing illuminated asphalt patch. At a height not larger than $5 \mathrm{~m}$ the lamplit asphalt road was not visible from the surface of Balaton, but the lamps themselves could be well seen (Horváth et al. 2010a). 
Based on this observation, we hypothesize that both phototaxis and polarotaxis may simultaneously influence the dispersal flight of crepuscular and nocturnal aquatic insects: the spectrum (intensity and colour) of light can lure water-seeking flying aquatic insects from remote distances (positive phototaxis caused by photopollution), then the horizontally polarized light reflected from the asphalt surface can attract and entrap the deceived insects (positive polarotaxis induced by polarized light pollution). We assume that these two kinds of light pollution and taxes together have a more harmful effect on the dispersal flight of water insects than they would have separately. To test this hypothesis, we carried out a multiple-choice field experiment, in which unpolarized and horizontally polarized light were offered simultaneously or alone for flying aquatic insects. We present here our results on the effects of these optical cues and their interaction in species and assemblage levels.

\section{Materials and Methods}

\section{Sampling site}

Our field experiment was performed in the Egyek-Pusztakócs marsh-land (Fig. 1A,B) of the Hortobágy National Park (47 33' 07" N, 20 53' 13" E; 10 km × 10 km, UTM grid code: DT 96), where, according to our measurements, the depth of water ranged up to $80 \mathrm{~cm}$ from the shore to the middle of the marshes in the sampling year (2011). Our sampling site had a high habitat diversity and diverse aquatic insect assemblages, furthermore lacked natural or man-made reflective surfaces and artificial light sources. Only a low-traffic public road without public lighting ran near the marsh.

\section{Date and time of sampling}

Our sampling was carried out five times between 6 and 17 July 2011. To eliminate the effect of natural ambient light and to increase the effectiveness of our artificial light sources, the samplings started between 21 and $24 \mathrm{~h}$ in full darkness after sunset (the point of times of sunset was between 
20:42 and 20:38 $\mathrm{h}=$ local summer time $=\mathrm{UTC}+2 \mathrm{~h}$ during the sampling period). On every sampling day the weather was still, cloudless and warm $\left(24-28{ }^{\circ} \mathrm{C}\right)$, which was ideal for aquatic insect dispersal.

\section{Experimental design}

To trigger insect polarotaxis, shiny, black, non-transparent agricultural plastic (polyvinyl-chloride) sheets were used as horizontal reflective surfaces. As a control, an unlit matte black canvas was laid on the ground. To enforce insect phototaxis, $125 \mathrm{~W}$ mercury vapor lamps (Kolorlux Mercury standard 125/27 1/24, General Electric Lighting) placed $2 \mathrm{~m}$ above the ground operated permanently during the experiment (Fig. 1B). These lamps could be seen from a wide range, because they were not mantled with any disc or plate. The lamps emitted light equally in 360 degrees. The spectrum of emitted light provided by the producer is shown in Fig. 1C. The majority of this spectrum falls in the visible $(400 \mathrm{~nm}<$ wavelength $<750 \mathrm{~nm}$ ) range, and there is only a very weak spectral band at $390 \mathrm{~nm}$ in the ultraviolet (UV) range. Thus, the lamps used in our experiment emitted practically only visible light.

The horizontal test surfaces $(2 \mathrm{~m} \times 2 \mathrm{~m})$ were simultaneously offered for flying aquatic insects in the following four situations: (1) lamplit matte black canvas eliciting phototaxis alone (PH) by the unpolarized direct lamplight, (2) unlit shiny black plastic sheet inducing polarotaxis alone (PO) by the horizontally polarized plastic-reflected ambient light, (3) lamplit shiny black plastic sheet eliciting photo- and polatoraxis together (PP) by the unpolarized direct lamplight and the strongly (i.e. with high degrees of linear polarization) and horizontally polarized plasticreflected lamplight, and (4) unlit matte black canvas as a control without phototaxis and polarotaxis (CO). These test surfaces were laid onto the ground in the corners of a square $(50 \mathrm{~m} \times 50 \mathrm{~m})$, the middle of which was positioned at $500 \mathrm{~m}$ from the edge of the shore line of the marsh (Fig. 1A,B). The test surfaces and lamps were randomly re-positioned hourly to eliminate site effects. 
All test surfaces were dry and non-sticky. They were edged with matte white canvas stripes of $10 \mathrm{~cm}$ width. These stripes helped to pin the plastic sheets to the ground with tent pegs as well as to capture the insects landed on the edge of the plastic. The plastic sheets were stretched in order to ensure that their surfaces were as smooth as possible.

The attracted aquatic insects stayed a minimum of 5-15 minutes on the test surfaces during which they tried to swim. This behaviour provided us an ideal possibility to capture them. The insect collection happened continuously, manually and separated hourly from every test surface. The collecting persons were changed randomly and hourly to reduce the human impact on the effectiveness of collection. The captured insects were preserved in $70 \%$ ethanol and identified later. At the end of each sampling day the test surfaces were removed from the experimental area.

The collected water beetles and bugs were identified under stereomicroscopes (Leica Wild 420 and Olympus vE3) in the laboratory, using the taxonomical keys and descriptions of Jansson (1986), Csabai (2000) and Csabai et al. (2002). Ochtebius, Limnebius, Heterocerus, Dryops and Cercyon spp. taxa were identified only to genus level, and Helophorus miutus/paraminutus were taken into account as pair species. The nomenclature followed Aukema and Rieger (1995) and Csabai (2003).

\section{Polarization measurements}

The reflection-polarization characteristics of the two different horizontal test surface types - matte black canvas and shiny (smooth) black plastic sheet - were measured by imaging polarimetry in the red $(650 \pm 40 \mathrm{~nm}=$ wavelength of maximal sensitivity \pm half bandwidth of the CCD detectors of the polarimeter), green $(550 \pm 40 \mathrm{~nm})$ and blue $(450 \pm 40 \mathrm{~nm})$ spectral ranges. The method has been described in detail elsewhere (Horváth and Varjú, 1997, 2004). Our rotating-analyzer, sequential imaging polarimeter was a digital camera (Pentax K10), the objective lens of which was mounted with a linear polarizer (PL-CIR HOYA, Japan; diameter: $52 \mathrm{~mm}$ ) that could be rotated manually. The sensitivity of the digital camera (Pentax K10) of our polarimeter did not allow measurement of 
the polarization of the weak light reflected from the lamplit test surfaces at night. Since the polarizing capability of our test surfaces do not depend on the intensity of illuminating light, we measured their reflection polarization at sunset under a totally cloudy, overcast sky (Fig. 2) in order to simulate the homogeneous spatial distribution of ambient light (starlight and very faint skyglow) during our field experiment performed at fully dark nights. During measurement, the angle of the optical axis of our polarimeter was $-45^{\circ}$ from the vertical.

An area of a polarizing reflector is sensed as water by polarotactic water insects, if (i) the degree of linear polarization $d$ of reflected light is higher than a threshold $d^{*}$, and (ii) the deviation $\Delta \alpha=\left|90^{\circ}-\alpha\right|$ of the angle of polarization $\alpha$ from the horizontal $\left(\alpha=90^{\circ}\right)$ is smaller than a threshold $\Delta \alpha^{*}$ (Horváth and Varjú 2004). Both thresholds $d^{*}$ and $\Delta \alpha^{*}$ depend on species. Based on our earlier results (Kriska et al. 2009), in Fig. 2 we used the values of $d^{*}=20 \%$ and $\Delta \alpha^{*}=10^{\circ}$, which are typical thresholds for dragonflies, mayflies and tabanid flies. We emphasize, however, that the use of other threshold values did not influence qualitatively our results and conclusions.

\section{Statistics}

To eliminate the differences in the absolute hourly numbers of individuals arising from the normal diel changes of dispersal activity, the hourly percentage distributions among the four treatments were used for analyses. To reveal the effects of the two different optical cues (intensity and polarization of light) and their interaction on the flying aquatic insects, two-way non-parametric MANOVA based on Bray-Curtis distance measure (Anderson 2001) and non-metric multidimensional scaling (NMDS) based on Euclidean distance measure were performed (Podani 2000). Two-way ANOVA analyses were used to explore the effects on total numbers of individuals and species (Zar 2010). During these assemblage-level analyses the Heterocerus spp. was eliminated from the dataset because of its semi-terrestrial mode of life. We used this species as a control (see Discussion). In species level, we performed two-way ANOVA analyses on the catches of abundant species (with $N>200$ ). During ANOVA and MANOVA analyses the presence and 
absence of two different treatments (lamplit/unlit, presence/lack of horizontal polarization) were used as factors. For statistical analyses we used the PAST v2.17c software package (Hammer et al. 2001).

\section{Results}

In all three (red, green, blue) parts of the visible spectrum the degrees of linear polarization $d$ of light reflected from the matte black canvas were low $(\sim 16 \pm 3 \%)$ relative to those reflected from the shiny black plastic sheet ( 52 $\pm 10 \%)$ used in our experiment (Table 1 and Fig. 2). Although both test surfaces reflected always nearly horizontally polarized light (i.e., the angle of polarization $\alpha$ was approximately $90^{\circ}$ from the vertical), only the shiny black plastic sheet was detected as water by polarotactic insects (see the blue regions in the fifth row of Fig. 2), because only this surface polarized strongly enough the reflected light. These reflection-polarization characteristics were practically independent of the wavelength of light (Table 1, Fig. 2) due to the blackness of our test surfaces.

A total of 46127 specimens belonging to 80 taxa of aquatic beetles (15587 individuals, 69 taxa) and water bugs (30540 individuals, 11 taxa) were captured during the five-evening sampling period (Supplementary Table S1). Hourly catch data (3 hours in each of 5 days, meaning 15 repetitions) for the four treatments were highly variable: (i) The lamplit canvas (phototaxis alone, PH) trapped 16-3793 individuals per hour (with many Heterocerus spp.). (ii) The unlit plastic sheet (polarotaxis alone, PO) caught 1-2689 individuals per hour. (iii) The lamplit plastic sheet (phototaxis and polarotaxis together, PP) captured 25-12614 individuals hourly. (iv) The hourly catches on the unlit canvas (control, $\mathrm{CO}$ ) ranged between 0 and 9 . The maximal number of species (72) was caught on the lamplit plastic sheet (PP), while the lowest number of species (7) was captured on the unlit canvas $(\mathrm{CO})$. The other two treatments $(\mathrm{PH}, \mathrm{PO})$ trapped the same number $(49,49)$ of species. 
Based on the total numbers of water beetle and bug individuals $\left(N_{\mathrm{i}}\right)$ and species $\left(N_{\mathrm{s}}\right)$ in Table 2 and Fig. 3, the lamplit shiny black plastic sheet (PP treatment: $N_{\mathrm{i}}=29682, N_{\mathrm{s}}=72$ ) was the most attractive to aquatic insects, while the unlit matte black canvas (CO treatment: $N_{\mathrm{i}}=13, N_{\mathrm{s}}=7$ ) trapped only negligible numbers of flying water insects. The sum of the total numbers of water beetle and bug individuals captured on the lamplit matte black canvas ( $\mathrm{PH}$ treatment: $N_{\mathrm{i}}=7922$ ) and the unlit shiny black plastic (PO treatment: $\left.N_{\mathrm{i}}=8510\right)$ is 16432 . The fact that the latter is much smaller than the total catch 29682 caught by the PP treatment provides experimental evidence for the synergistic interaction of phototaxis (elicited by the unpolarized direct lamplight) and polarotaxis (induced by the strongly and horizontally polarized plastic-reflected light) in the investigated aquatic insects. The synergistic interaction of phototaxis and polarotaxis statistically significantly affected only the percentage distribution of the numbers of individuals (Supplementary Table S2). In assemblage level, including hourly percentage distribution of all species, significant effects of phototaxis and polarotaxis and their interaction are also revealed (Supplementary Table S2).

The PH treatment had the highest percentage of the total variance for Enochrus bicolor (40.7 \%), Berosus spinosus (35.1\%) and Hydrobius fuscipes (40.8\%) (Supplementary Table S2). Thus, these species are more phototactic than polarotactic. Our results, among others, confirmed the wellknown fact, that most of the aquatic beetle and bug species display positive phototaxis, the strength of which depends on species (Nowinszky 2003, Klecka and Boukal 2011).

In Fig 4 the NMDS ordination also demonstrates that the attraction efficacies of the four treatments were very different: In the ordination plot the PP and PO treatments are separated, and the PH treatment was wedged between PP and PO with a minimal overlap with them. The catches of the PP treatment are characterized by the highest variance, while the $\mathrm{PO}, \mathrm{PH}$ and $\mathrm{CO}$ treatments have less and less variance, respectively.

There were 44 taxa, for which more than 10 individuals were captured during the sampling period (Supplementary Table S1). From these 44, there were 30 taxa (68\%) which were captured 
with distinctly higher numbers of individuals on the PP treatment than on the other test surfaces.

This means that for these 30 taxa phototaxis and polatoraxis acted together, and this synergism increased the number of attracted insects. 10 (e.g. Sigara falleni, Berosus frontifoveatus, Enochrus quadripunctatus, E. coarctatus, Hesperocorixa linnaei) from these 30 taxa were captured on the PP treatment with one order of magnitude greater numbers of individuals than on the other treatments. In the case of the PO treatment, 13 taxa $(29.5 \%)$ had somewhat higher catches than the other treatments. 7 (e.g. Hydroglyphus geminus, Hygrotus inaequalis, Limnebius spp., Ochthebius spp., Haliplus heydeni, H. fluviatilis) from these 13 taxa were captured with one order of magnitude higher numbers of individuals. Only the control taxon (Heterocerus spp.) was caught in a higher number of individuals on the PH treatment than on the other ones.

In the case of 9 from 14 mass-dispersing $(N>200)$ taxa $(64 \%)$, the two-way ANOVA tests revealed significant effects of the two optical cues (inducing phototaxis and polarotaxis) independently of each other as well as for their interaction (Supplementary Table S2). The dispersal behaviour of two other species (Sigara lateralis and Cymbiodyta marginella) was also significantly influenced by both of the mentioned optical cues separately, but not for their interaction. Only the polarotaxis turned out to be a significant factor affecting the flight behaviour of further two species (Helochares obscurus and Hygrotus inaequalis). The terrestrial Heterocerus spp. was the only taxon which was significantly connected with the PH treatment (Supplementary Table S2).

\section{Discussion}

To reveal the background of the earlier observation by Horváth et al. (2010a) that at night Hydrophilus piceus water beetles were visually trapped by a lamplit area of an asphalt road near a lake, we performed a multiple-choice experiment in the field. The main goal of our study was to explore and separate the effects of phototaxis and polarotaxis distracting the dispersal night-flight of primary aquatic insects. Our results showed the synergistic influence of phototaxis and polarotaxis on the night-flight of many aquatic insect species. 
The plastic sheets used in our field experiment reflected strongly $(d>50 \%)$ and horizontally ( $\alpha \approx 90^{\circ}$ from the vertical) polarized light, which is attractive to water-seeking aquatic insects (Schwind 1991; Wildermuth 1998; Bernáth et al. 2004; Horváth and Varjú 2004; Kriska et al. 2008; Lerner et al. 2008; Malik et al. 2008; Horváth et al. 2011; Csabai et al. 2012; Boda and Csabai 2013). The matte canvas reflected only weakly polarized light $(d<20 \%)$ being generally unattractive to water insects (Schwind 1995; Kriska et al. 2009). Therefore, the lamplit plastic sheet could induce simultaneously strong phototaxis and polarotaxis, while the lamplit canvas could practically elicit only strong phototaxis in flying aquatic insects. On the other hand, the unlit plastic sheet could induce weak polarotaxis, and the unlit canvas could elicit only weak phototaxis in water-seeking aerial water insects.

Since our test surfaces were black, their reflection-polarization characteristics were practically independent of the wavelength of light (Table 1, Fig. 2). Although the spectral sensitivities of phototaxis and polarotaxis in the investigated aquatic insects are unknown, we assume that their phototaxis and polarotaxis could be elicited in the visible $(400 \mathrm{~nm}<$ wavelength $<$ $750 \mathrm{~nm}$ ) part of the spectrum, since our light bulbs emitted unpolarized light practically only in the visible spectral range (Fig. 1C), which was also reflected from the test surfaces.

In numerous earlier field experiments (Schwind 1991, 1995; Horváth and Zeil 1996; Kriska et al. 1998, 2008, 2009; Wildermuth 1998; Bernáth et al. 2001; Horváth and Varjú 2004; Horváth et al. 2007, 2008, 2009, 2010a, 2011; Lerner et al. 2008; Málnás et al. 2011) it has been shown that water-seeking flying aquatic insects land on horizontal shiny black plastic sheets not due to positive phototaxis (induced by the intensity of plastic-reflected light), but exclusively due to positive polarotaxis (induced by the horizontal polarization of plastic-reflected light), otherwise they would also land on non-polarizing or only weakly polarizing bright test surfaces such as matte white canvas, white plastic sheet or aluminium foil. The same is true also for the aquatic insect species studied earlier (Csabai et al. 2006, 2012; Kriska et al. 2006; Boda and Csabai 2009, 2013) and also in the present work at the same marsh-land site. Thus, in the case of the PP treatment the relevant 
optical variable of the plastic sheet was only the horizontal polarization, rather than the higher intensity of reflected light. On the other hand, in the PP treatment the lamp emitted unpolarized light which could be directly perceived by flying insects. This unpolarized direct light was the other relevant optical variable in the PP treatment.

In our study, among the aquatic species captured en masse $(N>200)$ are common aquatic taxa and the majority are typical evening-flyers, and their strongest activity peaks are in the summer months (Csabai et al. 2012; Boda and Csabai 2013). However, non-aquatic insects were ignored, except for one taxon, the variegated mud-loving beetles (Heterocerus spp.). These insects are semiterrestrial, but typical shoreline inhabitants, spending much time burrowing in damp soil around ponds, lakes or rivers, thus they tend to live always close to the edge of the water or close to the high-tide mark. These beetles are good flyers and possess strong positive phototaxis (Scapini et al. 1993). Since on the basis of Supplementary Table S1 in our PO treatment they were captured only in a negligible number $\left(N_{\mathrm{PO}}=39\right.$, which is only $0.95 \%$ of $\left.N_{\text {total }}=4087\right)$, while in the PH treatment we captured $N_{\mathrm{PH}}=3018(73.84 \%)$ individuals from this taxon, it seems to be exclusively phototactic, as also concluded by earlier investigators (Csabai et al. 2006, 2012; Boda and Csabai 2013). However, in the PP treatment we captured only $N_{\mathrm{PP}}=1029$ (25.18\%) Heterocerus (Supplementary Table S1), in spite of the presence of intense unpolarized direct light (emitted by the lamp used) presenting a bright phototactic stimulus. The individuals of this taxon were statistically significantly attracted by the PH treatment, but not significantly by the PO treatment (Supplementary Table S2). From these we conclude that the semiterrestrial Heterocerus adults are phototactic and avoid horizontally polarized light (like the desert locust Schistocerca gregaria being a terrestrial insect with negative polarotaxis; Shashar et al. 2005) if they do not want to oviposit.

Among the taxa captured with more than 10 individuals, almost $70 \%$ were caught with the highest numbers of individuals on the PP treatment (Supplementary Table S1). All of these species display positive polarotaxis, as primary aquatic insects generally (Schwind 1991, 1995; Wildermuth 
1998; Horváth and Varjú 2004; Csabai et al. 2006; Lerner et al. 2008), and they display also more or less strong positive phototaxis. These findings indicate that the interaction of light intensity and polarization has a very strong influence on the flight activity of the majority of the investigated species, and this synergistic effect is much stronger than the effect induced separately by the two different optical cues.

About $30 \%$ of the collected species were attracted with higher numbers of individuals by the PO treatment, than by the other treatments. It is a well-known fact, that not all aquatic insect species possess strong positive phototaxis, and these are always rare species in light traps (Benedek and Jászai 1972; Klecka and Boukal 2011). Most of the species that preferred our PO treatment belong to Haliplidae (Haliplus ruficollis, H. fluviatilis), Hydraenidae (Limnebius spp., Ochthebius spp.) and Dytiscidae (Hygrotus impressopunctatus, H. inaequalis, Graptodytes bilineatus, Hydroglyphus geminus, Laccophilus minutus). In the Hydrophilidae family, Helochares obscurus is known to possess weak positive phototaxis (Klecka and Boukal 2011). In our samples it occurred almost with the same numbers of individuals on the PP and PO treatments, but the $\mathrm{PH}$ treatment captured it in a much lower number. According to light trap samplings (Weigelhofer et al. 1992), Sigara lateralis (like the majority of species of the Corixidae family) displays a strong positive phototaxis. In our experiment, the PO treatment attracted approximately $3200 \mathrm{~S}$. lateralis individuals. The attractiveness of the PP and $\mathrm{PH}$ treatments to this species was the half $(N \approx 1600)$ and the quarter $(N \approx 700)$, respectively, of that of the PO treatment. All of the above-mentioned species are much more polarotactic than phototactic. Thus, the interaction between light intensity and horizontally polarized light does not produce a significantly higher luring effect than horizontal polarization alone. Nevertheless, the weak strengthening effect of such an interaction is detectable in most of these species.

Some species occurred with null or near zero numbers of individuals on the PO treatment, while their catches were large on both lamplit test surfaces, especially on the PP treatment. The majority of these species have larger bodies (e.g. Hydrophilus piceus, H. aterrimus, Graphoderus 
austriacus $)$. In our experiment we used relatively small $(2 \mathrm{~m} \times 2 \mathrm{~m})$ test surfaces, which size may be inappropriate as habitat for these large-bodied aquatic insects, that thus did not land on our surfaces. However, if these small-sized surfaces were lamplit, the unpolarized direct lamplight could also attract these insects from a distance (because of their strong positive phototaxis). Thus, our small, strongly and horizontally polarizing PP surface could trap these large-bodied species, too.

The small size of our test surfaces can also explain the avoidance of the PO treatment by some other species, for example Hydroglyphus geminus. Phenology drives the timing of water seeking by aquatic beetles and bugs (Boda and Csabai 2009). In certain periods these species need smaller and shallow waters (mainly for breeding and oviposition), while at other times they are looking for larger permanent water bodies. During the latter period it is logical to avoid small, horizontally polarizing spots meaning small water bodies. Hydrobius fuscipes, for instance, flies typically in spring and autumn, when it is seeking smaller water bodies (Boda and Csabai 2013). In our summer experiment this species was lured in a higher number $N_{\mathrm{PH}}=78(16.12 \%$ relative to $\left.N_{\text {total }}=484\right)$ by the PH treatment and in a negligible number $N_{\mathrm{PO}}=5(1.03 \%)$ by the PO treatment, while in a large number $N_{\mathrm{PP}}=401(82.85 \%)$ by the PP treatment. Thus, Hydrobius fuscipes might have been attracted to the PP more by the higher intensity than the horizontal polarization. Nevertheless, since $N_{\mathrm{PP}}=401>>3=N_{\mathrm{PH}}(=78)+N_{\mathrm{PO}}(=5)$, the synergistic interaction of phototaxis and polarotaxis is evident also in the case of Hydrobius fuscipes, which species is not attracted by the horizontal polarization (PO) alone in the summer period studied by us.

The flight behaviour elicited by the synergistic interaction of phototaxis and polarotaxis can occur in all aquatic insect species. Unfortunately, this phenomenon is not as rare in nature as we think at first. Lamplit car parks, solar panels near indicator lighting and illuminated glass buildings, for example, have the potential to significantly disrupt the ecosystem by simultaneous photopollution and polarized light pollution (Bernáth et al. 2001; Longcore and Rich 2004; Rich 
and Longcore 2006; Horváth et al. 2009, 2010a). The follow-up investigation of the generality of this phenomenon could be an interesting and important task of future research.

Acknowledgements: We thank Judit Csaba, Judit Horváth, Bence Kovács, Erika Mihaliczku, Barbara Palombi, Renáta Tóth, Zsuzsanna Urbán and Vivien Viski (University of Debrecen, Hungary) for their extensive help during our field experiment. Gábor Horváth is grateful to the German Alexander von Humboldt Foundation for the three-month research fellowship 3.3UNG/1073032 STP from 1 June to 31 August 2013 in the University of Regensburg.

\section{References}

Anderson MJ (2001) A new method for non-parametric multivariate analysis of variance. Austral Ecol 26:32-46.

Aukema B, Rieger C (ed) (1995) Catalogue of the Heteroptera of the Palearctic Region. Enicocephalomorpha, Dipsocoromorpha, Nepomorpha, Gerromorpha and Leptopodomorpha. Vol. I, The Netherlands: The Netherlands Entomological Society, Amsterdam

Benedek P, Jászai VE (1972) On the migration of Corixidae (Heteroptera) based on light trap data. Acta Zool Acad Sci Hung 19:1-9.

Bernáth B, Gál J, Horváth G (2004) Why is it worth flying at dusk for aquatic insects? Polarotactic water detection is easiest at low solar elevations. J Exp Biol 207:755-765.

Bernáth B, Szedenics G, Molnár G, Kriska G, Horváth G (2001) Visual ecological impact of "shiny black anthropogenic products" on aquatic insects: oil reservoirs and plastic sheets as polarized traps for insects associated with water. Arch Nat Conservat Landsc Res 40:89-109.

Bernáth B, Szedenics G, Wildermuth H, Horváth G (2002) How can dragonflies discern bright and dark waters from a distance? The degree of polarization of reflected light as a possible cue for dragonfly habitat selection. Freshwater Biol 47:1707-1719. 
Bilton DT, Freeland JR, Okamura B (2001) Dispersal in freshwater invertebrates. Annu Rev Ecol Syst 32:159-181.

Boda P, Csabai Z (2009) Seasonal and diel dispersal activity characteristics of Sigara lateralis (Leach, 1817) (Heteroptera: Corixidae) with special emphasis of the possible environmental factors and breeding state. Aquat Insect 31:301-314.

Boda P, Csabai Z (2013) When do beetles and bugs fly? A unified scheme for describing seasonal flight behaviour of highly dispersing primary aquatic insects. Hydrobiologia 703:133-147.

Choi H, Kim H, Kim JG (2009) Landscape analysis of the effects of artificial lighting around wetland habitats on the giant water bug Lethocerus deyrollei in Jeju Island. J Ecol Field Biol $32: 83-86$.

Csabai Z, Boda P; Bernáth B, Kriska Gy, Horváth G (2006) A “polarization sun-dial” dictates the optimal time of day for dispersal by flying aquatic insects. Freshwater Biol 51:1341-1350.

Csabai Z, Gidó Zs, Szél Gy (2002) Vízibogarak kishatározója II. (Coleoptera: Georissidae, Spercheidae, Hydrochidae, Helophoridae, Hydrophilidae) [A guide for the identification of water beetles of Hungary, II. (in Hungarian with English abstract)]. Budapest, In: Vízi Természet- és Környezetvédelem 16., Környezetgazdálkodási Intézet.

Csabai Z (2000) Vízibogarak kishatározója I. (Coleoptera: Haliplidae, Hygrobiidae, Dytiscidae, Noteridae, Gyrinidae). [A guide for the identification of water beetles of Hungary, I. (in Hungarian with English abstract)]. Budapest, In: Vízi Természet- és Környezetvédelem 15. Környezetgazdálkodási Intézet.

Csabai Z (2003) Vízibogarak kishatározója III. (Kiegészítő kötet) [A guide for the identification of water beetles of Hungary, III. Supplement band (in Hungarian with English abstract)]. Budapest, In: Vízi Természet és Környezetvédelem 17., Környezetgazdálkodási Intézet.

Csabai Z, Kálmán Z, Szivák I, Boda P (2012) Diel flight behaviour and dispersal patterns of aquatic Coleoptera and Heteroptera species with special emphasis on the importance of seasons. Naturwissenschaften 99:751-765. 
Frank KD (2006) Effects of artificial night light on moths. In: Rich C, Longcore T. (eds.): Ecological Consequences of Artificial Night Lighting. Washington, Island Press., p. 345-364. Hammer O, Harper DAT, Ryan PD (2001) PAST: Paleontological statistics software package for education and data analysis. Palaeontologia Electronica 4(1): 9 pp.

Horváth G, Blahó M, Egri Á, Kriska Gy, Seres I, Robertson B (2010a) Reducing the maladaptive attractiveness of solar panels to polarotactic insects. Conserv Biol 24:1644-1653.

Horváth G, Kriska G, Malik P, Hegedüs R, Neumann L, Åkesson S, Robertson B (2010b) Asphalt Surfaces as Ecological Traps for Water-Seeking Polarotactic Insects: How can the Polarized Light Pollution of Asphalt Surfaces be Reduced? Series: Environmental Remediation Technologies, Regulations and Safety. New York, USA, Nova Science Publishers Inc.

Horváth G, Kriska G, Malik P, Robertson B (2009) Polarized light pollution: a new kind of ecological photopollution. Front Ecol Environ 7:317-325.

Horváth G, Majer J, Horváth L, Szivák I, Kriska G (2008) Ventral polarization vision in tabanids: horseflies and deerflies (Diptera: Tabanidae) are attracted to horizontally polarized light. Naturwissenschaften 95:1093-1100.

Horváth G, Malik P, Kriska G, Wildermuth H (2007) Ecological traps for dragonflies in a cemetery: the attraction of Sympetrum species (Odonata: Libellulidae) by horizontally polarizing black gravestones. Freshwater Biol 52:1700-1709.

Horváth G, Móra A, Bernáth B, Kriska G (2011) Polarotaxis in non-biting midges: female chironomids are attracted to horizontally polarized light. Physiol Behav 104:1010-1015.

Horváth G, Varjú D (1997) Polarization pattern of freshwater habitats recorded by video polarimetry in red, green and blue spectral ranges and its relevance for water detection by aquatic insects. J Exp Biol 200:1155-1163.

Horváth G, Varjú D (2004) Polarized Light in Animal Vision - Polarization Patterns in Nature. Heidelberg, Berlin, New York: Springer.

Horváth G, Zeil J (1996) Kuwait oil lakes as insect traps. Nature 379:303-304. 
Jansson A (1986) The Corixidae (Heteroptera) of Europe and some adjacent regions. Acta Entomol Fenn 47:1-94.

Klecka J, Boukal DS (2011) Lazy ecologist's guide to water beetle diversity: Which sampling methods are the best? Ecol Indic 11:500-508.

Kriska G, Bernáth B, Farkas R, Horváth G (2009) Degrees of polarization of reflected light eliciting polarotaxis in dragonflies (Odonata), mayflies (Ephemeroptera) and tabanid flies (Tabanidae). J Insect Physiol 55:1167-1173.

Kriska G, Csabai Z, Boda P, Malik P, Horváth G (2006) Why do red and dark-coloured cars lure aquatic insects? The attraction of water insects to car paintwork explained by reflectionpolarisation signals. Proc R Soc Lond B 273:1667-1771.

Kriska G, Horváth G, Andrikovics S (1998) Why do mayflies lay their eggs en masse on dry asphalt roads? Water-imitating polarized light reflected from asphalt attracts Ephemeroptera. J Exp Biol 201:2273-2286.

Kriska G, Malik P, Szivák I, Horváth G (2008) Glass buildings on river banks as "polarized light traps" for mass-swarming polarotactic caddis flies. Naturwissenschaften 95:461-467.

Lerner A, Meltser N, Sapir N, Erlick C, Shashar N, Broza M. (2008) Reflected polarization guides chironomid females to oviposition sites. J Exp Biol 211:3536-3543.

Longcore T, Rich C (2004) Ecological light pollution. Front Ecol Environ 2:191-198.

Malik P, Hegedüs R, Kriska G, Horváth G (2008) Imaging polarimetry of glass buildings: Why do vertical glass surfaces attract polarotactic insects? Appl Optics 47:4361-4374

Málnás K, Polyák L, Prill É, Hegedüs R, Kriska G, Dévai G, Horváth G, Lengyel S (2011) Bridges as optical barriers and population disruptors for the mayfly Palingenia longicauda: An overlooked threat to freshwater biodiversity? J Insect Conserv 15:823-832.

Nowinszky L (2003) The Handbook of Light Trapping. Szombathely, Hungary: Savaria University Press. 
Nowinszky L (2004) Nocturnal illumination and night flying insects. Appl Ecol Environ Res 2:1752.

Podani J (2000) Introduction to the Exploration of Multivariate Biological Data. Leiden, The Netherlands: Backhuys Publishers.

Rich C, Longcore T (2006) Ecological Consequences of Artificial Night Lighting. Washington, DC: Island Press.

Scapini F, Mascagni A, Sforzi A (1993) Zonal recovery and orientation in respect to various stimuli of Heterocerus fenestratus Thunberg, 1784 (Coleoptera, Heteroceridae). J Insect Physiol 39:665-675.

Schwind R (1991) Polarization vision in water insects and insects living on a moist substrate. J Comp Physiol A 169:531-540.

Schwind R (1995) Spectral regions in which aquatic insects see reflected polarized light. J Comp Physiol A 177:439-448.

Shashar N, Sabbah S, Aharoni N (2005) Migrating locusts can detect polarized reflections to avoid flying over the sea. Biology Letters 1: 472-475

Weigelhofer G, Weissmair W, Waringer J (1992) Night migration activity and the influence of meteorological parameters on light-trapping for aquatic Heteroptera. Zool Anz 229:209-218.

Wildermuth H, Horváth G (2005) Visual deception of a male Libellula depressa by the shiny surface of a parked car (Odonata: Libellulidae). Int J Odonatol 8:97-105.

Wildermuth H (1998) Dragonflies recognize the water of rendezvous and oviposition sites by horizontally polarized light: a behavioural field test. Naturwissenschaften 85:297-302.

Yee DA, Taylor S, Vamosi SM (2009) Beetle and plant density as cues initiating dispersal in two species of adult predaceous diving beetles. Oecologia 160:25-36.

Zar J (2010) Biostatistical analysis. Upper Saddle River. New Jersey: Prentice Hall Inc. 


\section{Tables}

Table 1: Degree of polarization $d(\%$, mean \pm standard deviation $)$ and angle of polarization $\alpha$ (degree, clockwise from the vertical, mean \pm standard deviation) of light reflected from the horizontal matte black canvas and the shiny black plastic sheet used in our field experiment and measured by imaging polarimetry in the red $(650 \mathrm{~nm})$, green $(550 \mathrm{~nm})$ and blue $(450 \mathrm{~nm})$ parts of the spectrum. The values of $d$ and $\alpha$ change around their mean, because the reflection-polarization characteristics of light reflected from the test surfaces depend on the angle of incidence $\beta$ relative to the surface, and $\beta$ varied from point to point in the field of view $\left(30^{\circ} \times 50^{\circ}\right)$ of our polarimeter.

\begin{tabular}{|l|c|c|c|c|}
\hline & \multicolumn{2}{|c|}{ matte black canvas } & \multicolumn{2}{c|}{ shiny black plastic } \\
\hline & $d(\%)$ & $\alpha\left(^{\circ}\right)$ & $d(\%)$ & $\alpha\left(^{\circ}\right)$ \\
\hline red & $15.9 \pm 3.0$ & $89.0 \pm 5.6$ & $51.8 \pm 11.0$ & $89.8 \pm 8.3$ \\
\hline green & $16.0 \pm 2.8$ & $89.1 \pm 3.6$ & $52.0 \pm 10.6$ & $89.7 \pm 8.2$ \\
\hline blue & $16.2 \pm 2.8$ & $89.6 \pm 4.2$ & $53.4 \pm 10.1$ & $89.4 \pm 7.9$ \\
\hline
\end{tabular}


Table 2: Numbers $N_{\mathrm{i}}$ and $N_{\mathrm{s}}$, and percentage (\%: $\left.N_{\mathrm{i}} / N_{\text {total }}, N_{\mathrm{i}} / N_{\text {total }}\right)$ of captured individuals $\left(N_{\mathrm{i}}\right)$ and species $\left(N_{\mathrm{s}}\right)$ in each treatment during the whole sampling period. A given insect individual could land only on one test surface, because after landing it was captured, while a given insect species could also occur on several test surfaces. PH: lamplit matte black canvas inducing phototaxis alone, PO: unlit shiny black plastic sheet eliciting polarotaxis alone, PP: lamplit shiny black plastic sheet inducing photo- and polatoraxis together, $\mathrm{CO}$ : unlit matte black canvas as a control without phototaxis and polarotaxis.

\begin{tabular}{|l|c|c|c|c|c|c|c|c|c|}
\hline \multirow{3}{*}{ Number of } & \multicolumn{7}{|c|}{ Treatment } & \multirow{2}{*}{ Total } \\
\cline { 2 - 11 } & \multicolumn{2}{|c|}{ PH } & \multicolumn{2}{c|}{ PO } & \multicolumn{2}{c|}{ PP } & \multicolumn{2}{c|}{$\mathbf{C O}$} & \\
\cline { 2 - 10 } & $\boldsymbol{N}_{\mathbf{i}}$ & $\mathbf{\%}$ & $\boldsymbol{N}_{\mathbf{i}}$ & $\mathbf{\%}$ & $\boldsymbol{N}_{\mathbf{i}}$ & $\mathbf{\%}$ & $\boldsymbol{N}_{\mathbf{i}}$ & $\mathbf{\%}$ & $\boldsymbol{N}_{\mathbf{i}}$ \\
\hline beetle individuals & 4284 & 27.48 & 2332 & 14.96 & 8960 & 57.48 & 11 & 0.08 & 15587 \\
\hline bug individuals & 3638 & 11.91 & 6178 & 20.23 & 20722 & 67.85 & 2 & 0.01 & 30540 \\
\hline sum (beetles+bugs) & 7922 & 17.17 & 8510 & 18.45 & 29682 & 64.35 & 13 & 0.03 & 46127 \\
\hline & $\boldsymbol{N}_{\mathbf{s}}$ & $\mathbf{\%}$ & $\boldsymbol{N}_{\mathbf{s}}$ & $\mathbf{\%}$ & $\boldsymbol{N}_{\mathbf{s}}$ & $\mathbf{\%}$ & $\boldsymbol{N}_{\mathbf{s}}$ & $\mathbf{\%}$ & $\boldsymbol{N}_{\mathbf{s}}$ \\
\hline beetle species & 42 & 60.87 & 40 & 57.97 & 62 & 89.86 & 6 & 8.70 & 69 \\
\hline bug species & 7 & 63.64 & 9 & 81.82 & 10 & 90.91 & 1 & 9.09 & 11 \\
\hline sum (beetles+bugs) & 49 & 61.25 & 49 & 61.25 & 72 & 90.00 & 7 & 8.75 & 80 \\
\hline
\end{tabular}




\section{Figures with Legends}

Figure 1: (A) Photograph of the Egyek-Pusztakócs marsh-land, our study site (photo of Hagymás Basin: by courtesy of Dr. Szabolcs Lengyel). The black dot in the inset marks the location of the study site in Hungary. (B) Schematic representation of our experimental design. (C) Spectrum of light (provided by the producer) emitted by the $125 \mathrm{~W}$ mercury vapor lamps used in the experiment.

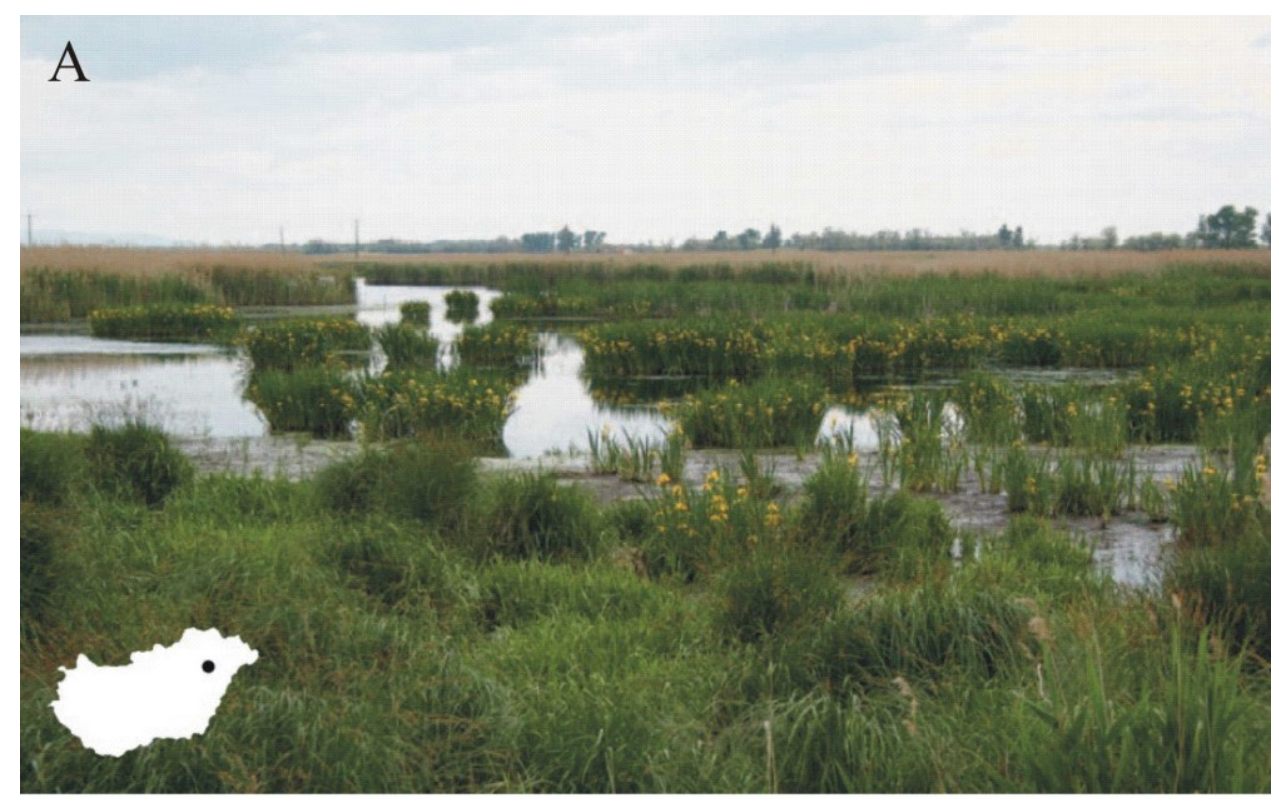

B

polarization treatment $(\mathrm{PO})$

unlit shiny black plastic

polarotaxis alone

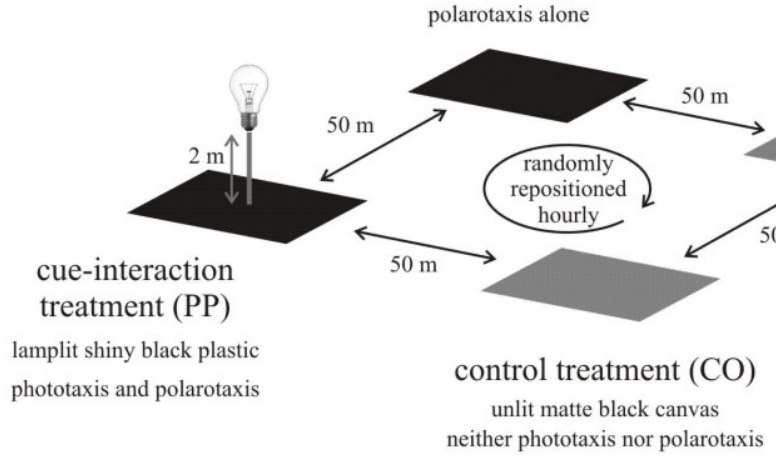

$\mathrm{C}$

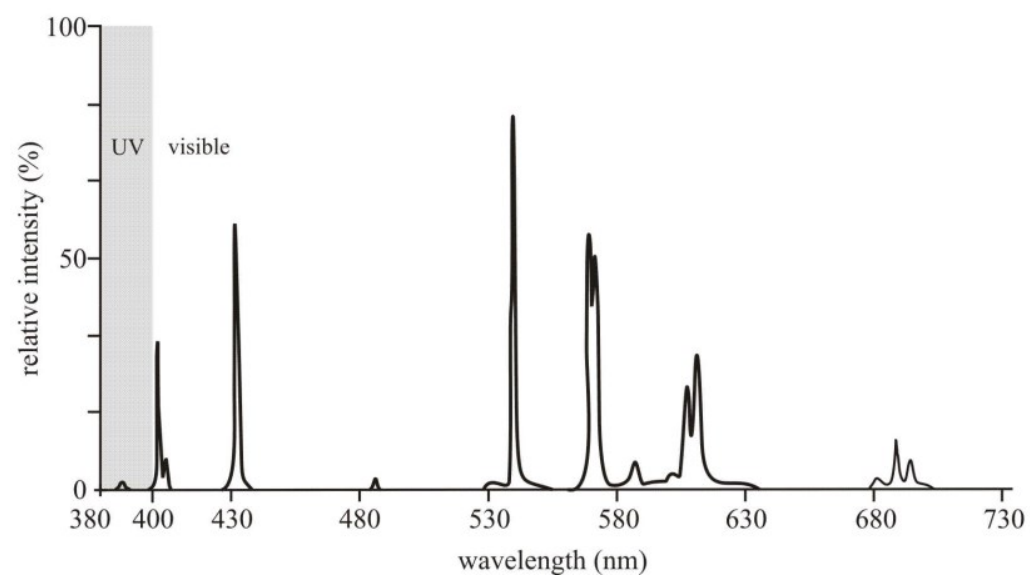


Figure 2: Reflection-polarization patterns of the horizontal matte black canvas (left) and the shiny black plastic sheet (right) used in our field experiment measured by imaging polarimetry in the red, green and blue parts of the spectrum. In row 2 intensity $I$ is the total intensity of reflected light. In the photograph rectangles show the areas from which the polarization data in Table 1 originate. In the $\alpha$-patterns double-headed arrows show the direction of polarization of light reflected from the test surfaces. The lowermost row represents the area detected as water (blue) by polarotactic flying aquatic insects. This area has the following polarization characteristics: $d>20 \%, 80^{\circ}<\alpha<100^{\circ}$ (from the vertical).

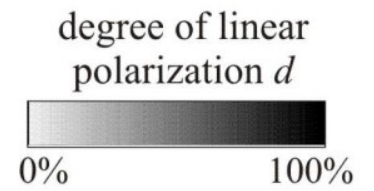

area detected as water
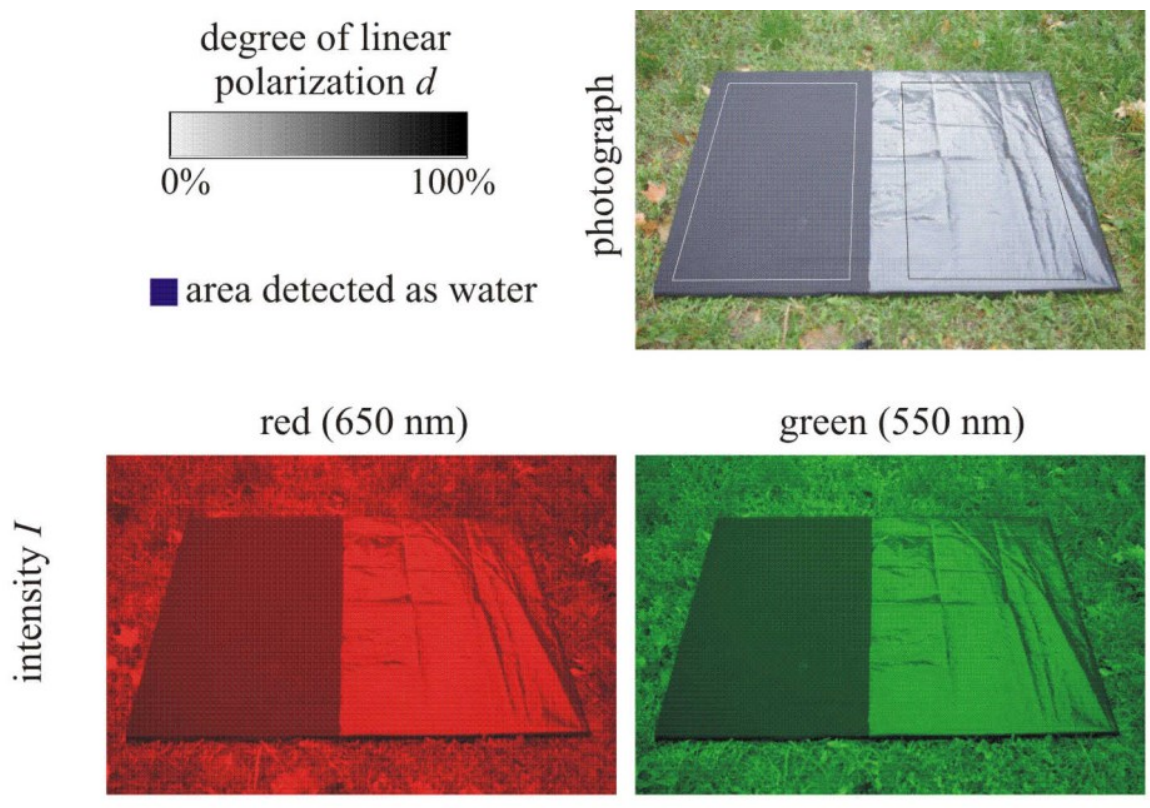

芯
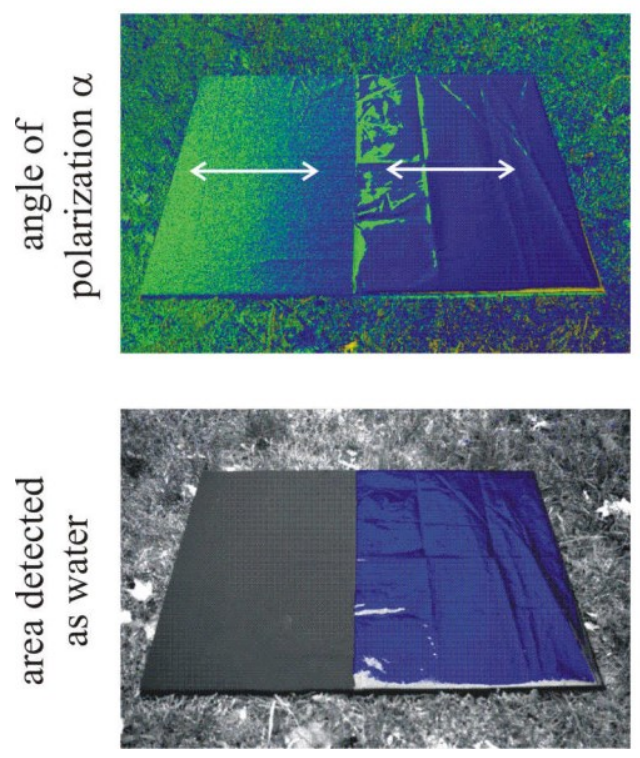

green $(550 \mathrm{~nm})$
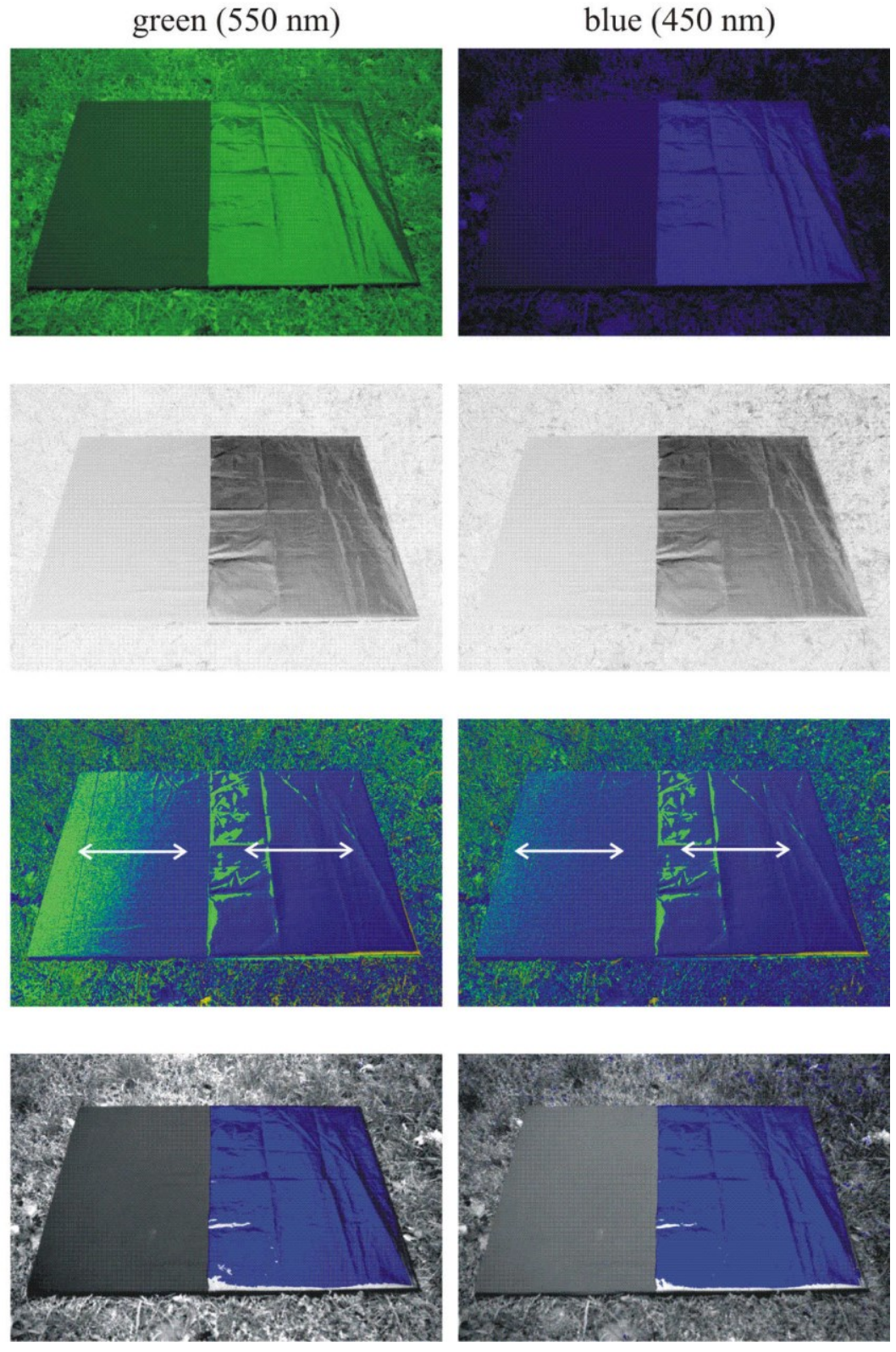
Figure 3: Relative number of individuals (A) and species (B) among the experimental treatments PH (lamplit matte black canvas inducing phototaxis alone), PO (unlit shiny black plastic sheet eliciting polarotaxis alone), PP (lamplit shiny black plastic sheet inducing photo- and polatoraxis together), $\mathrm{CO}$ (unlit matte black canvas as a control without phototaxis and polarotaxis). The interaction of light intensity and horizontal polarization resulted in the most attractive test surface, the PP. Grey box: interquartile range. Inner line: median. Dot: outlier. Whisker: standard error.
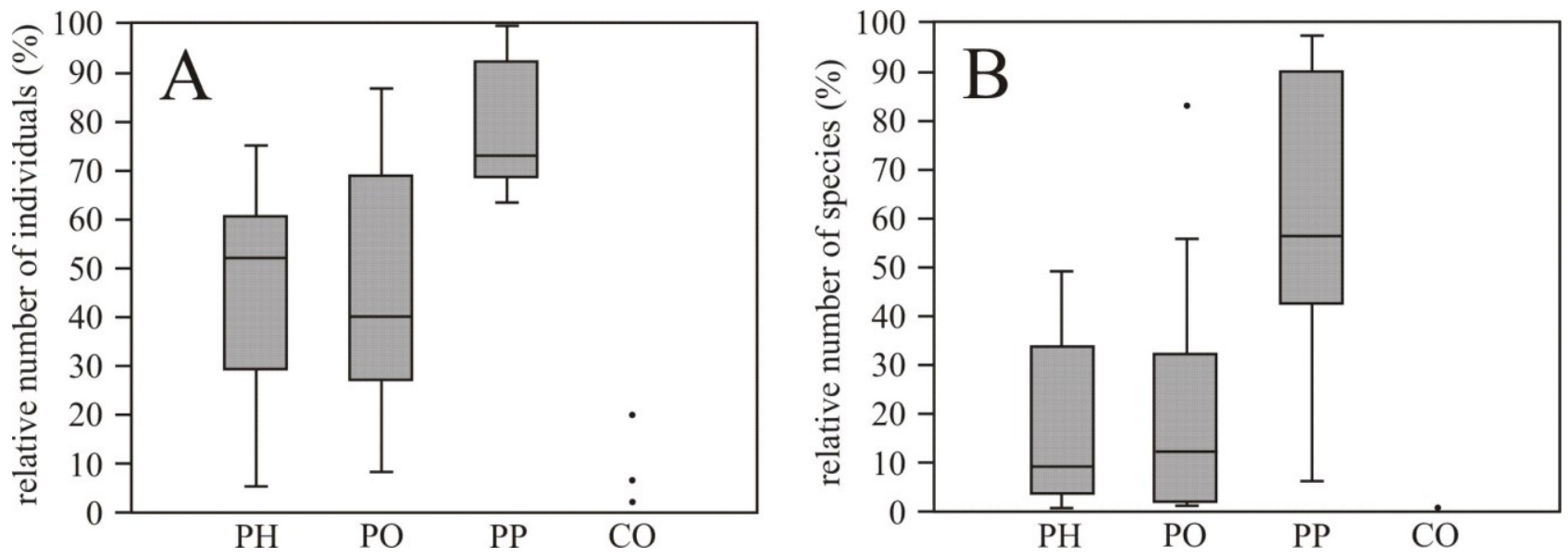

Figure 4: (A) Differentiation of the hourly catches of the four treatments (PH: phototaxis, PO: polarotaxis, PP: interaction of phototaxis and polarotaxis, $\mathrm{CO}$ : control) on the non-metric multidimensional scaling (MNDS) ordination plot based on Euclidean distance measure. The highest variance occurs for the PP treatment, the different treatments are more or less separated from each other. (B) Shepard diagram for the ordination (final stress $=0.1305$ ).

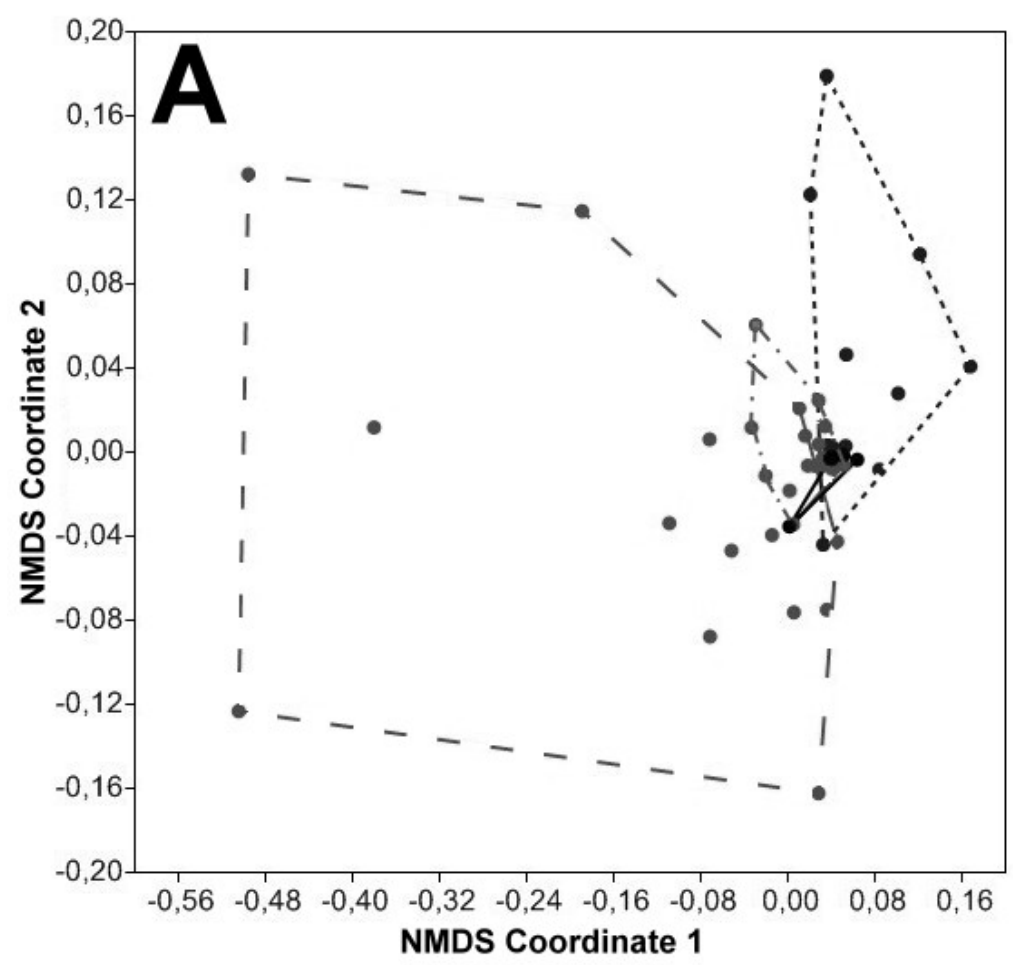

Legend:

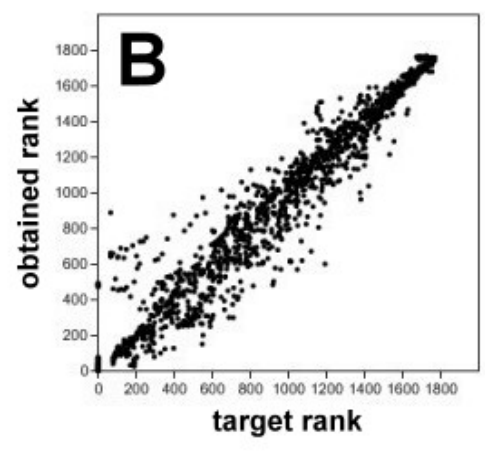


Supplementary Table S1: Collected taxa, numbers of individuals captured from the four different treatments (PH: lamplit matte black canvas inducing phototaxis alone, PO: unlit shiny black plastic sheet eliciting polarotaxis alone, PP: lamplit shiny black plastic sheet inducing photo- and polatoraxis together, $\mathrm{CO}$ : unlit matte black canvas as a control without phototaxis and polarotaxis) and the total numbers of individuals $\left(N_{\text {total }}\right)$.

\begin{tabular}{|c|c|c|c|c|c|}
\hline taxon & PH & PO & $\mathbf{P P}$ & $\mathbf{C O}$ & $N_{\text {total }}$ \\
\hline Sigara falleni (Fieber, 1848) & 2745 & 2774 & 18154 & 2 & 23675 \\
\hline Sigara lateralis (Leach, 1817) & 714 & 3204 & 1685 & 0 & 5603 \\
\hline Heterocerus spp. & 3018 & 39 & 1029 & 0 & 4087 \\
\hline Berosus frontifoveatus Kuwert, 1888 & 184 & 253 & 2087 & 0 & 2524 \\
\hline Enochrus quadripunctatus (Herbst, 1797) & 168 & 38 & 2269 & 0 & 2475 \\
\hline Enochrus bicolor (Fabricius, 1792) & 171 & 20 & 833 & 0 & 1024 \\
\hline Hydroglyphus geminus (Fabricius, 1792) & 0 & 807 & 63 & 3 & 873 \\
\hline Cymbiodyta marginella (Fabricius, 1792) & 194 & 18 & 597 & 0 & 809 \\
\hline Helochares obscurus (O. F. Müller, 1776) & 81 & 338 & 359 & 3 & 781 \\
\hline Sigara striata (Linnaeus, 1775) & 85 & 115 & 509 & 0 & 709 \\
\hline Berosus spinosus (Steven, 1808) & 127 & 15 & 369 & 0 & 511 \\
\hline Hydrobius fuscipes (Linnaeus, 1758) & 78 & 5 & 401 & 0 & 484 \\
\hline Hygrotus inaequalis (Fabricius, 1776) & 16 & 265 & 37 & 0 & 318 \\
\hline Hesperocorixa linnei (Fieber, 1848) & 40 & 21 & 192 & 0 & 253 \\
\hline Enochrus coarctatus (Gredler, 1863) & 41 & 13 & 125 & 0 & 179 \\
\hline Enochrus affinis (Thunberg, 1794) & 32 & 53 & 83 & 1 & 169 \\
\hline Cymatia rogenhoferi (Fieber, 1864) & 34 & 11 & 75 & 0 & 120 \\
\hline Limnebius spp. & 0 & 107 & 11 & 0 & 118 \\
\hline Enochrus melanocephalus (Olivier, 1792) & 15 & 3 & 87 & 0 & 105 \\
\hline Laccophilus minutus (Linnaeus, 1758) & 4 & 72 & 28 & 0 & 104 \\
\hline Callicorixa praeusta (Fieber, 1848) & 8 & 35 & 49 & 0 & 92 \\
\hline Coelostoma orbiculare (Fabricius, 1775) & 10 & 0 & 81 & 0 & 91 \\
\hline Haliplus ruficollis (De Geer, 1774) & 11 & 49 & 27 & 2 & 89 \\
\hline Cercyon spp. & 18 & 2 & 64 & 0 & 84 \\
\hline Hygrotus impressopuctatus (Schaller, 1783) & 2 & 64 & 11 & 0 & 77 \\
\hline Paracorixa concinna (Fieber, 1848) & 12 & 14 & 48 & 0 & 74 \\
\hline Anacaena limbata (Fabricius, 1792) & 7 & 25 & 37 & 0 & 69 \\
\hline Enochrus testaceus (Fabricius, 1801) & 12 & 1 & 53 & 0 & 66 \\
\hline Hydrophilus aterrimus Eschscholtz, 1822 & 21 & 0 & 37 & 0 & 58 \\
\hline Ochtebius spp. & 1 & 51 & 1 & 1 & 54 \\
\hline Laccophilus poecilus Klug, 1834 & 6 & 9 & 38 & 0 & 53 \\
\hline Graphoderus austriacus (Sturm, 1834) & 16 & 0 & 24 & 0 & 40 \\
\hline Hydrophilus piceus (Linnaeus, 1758) & 16 & 0 & 20 & 0 & 36 \\
\hline Helophorus minutus/paraminutus & 3 & 13 & 17 & 0 & 33 \\
\hline Berosus signaticollis (Charpentier, 1825) & 3 & 2 & 27 & 0 & 32 \\
\hline Haliplus heydeni Wehncke, 1875 & 4 & 11 & 6 & 0 & 21 \\
\hline
\end{tabular}




\begin{tabular}{|l|c|c|c|c|c|}
\hline Graptodytes bilineatus (Sturm, 1835) & 3 & 10 & 3 & 0 & 16 \\
\hline Haliplus fluviatilis Aube, 1836 & 0 & 16 & 0 & 0 & 16 \\
\hline Hygrotus parallellogrammus (Ahrens, 1812) & 0 & 0 & 15 & 0 & 15 \\
\hline Peltodytes caesus (Duftschmid, 1805) & 1 & 9 & 5 & 0 & 15 \\
\hline Corixa affinis Leach, 1817 & 0 & 3 & 8 & 0 & 11 \\
\hline Enochrus ochropterus (Marsham, 1802) & 3 & 0 & 8 & 0 & 11 \\
\hline Ilybius quadriguttatus (Lacordaire, 1835) & 1 & 0 & 10 & 0 & 11 \\
\hline Ilybius subaeneus Erichson, 1837 & 2 & 0 & 9 & 0 & 11 \\
\hline
\end{tabular}

Further species with low numbers (ranging from 9 to 1) of captured individuals (the numbers are referred to the collected individuals from the four treatment together): 9: Berosus fulvus (Kuwert, 1888), Hydaticus grammicus (Germar, 1830), Hydroporus angustatus Sturm, 1835, 8: Limnoxenus niger Zschach, 1788, Liopterus haemorrhoidalis (Fabricius, 1787); 7: Cybister lateralimarginalis (De Geer, 1774), Ilybius ater (De Geer, 1774); 6: Ilybius guttiger (Gyllenhal, 1808), Rhantus grapii (Gyllenhal, 1808); 5: Hydrochus crenatus (Fabricius, 1792), Hydroporus striola (Gyllenhal, 1826); 4: Bidessus nasutus Sharp, 1887, Enochrus ater (Kuwert, 1888), Helophorus griseus Herbst, 1793, Hydrochara flavipes (Steven, 1808), Hydrovatus cuspidatus Kunze, 1818, Rhantus suturalis (MacLeay, 1825); 3: Dryops spp., Haliplus immaculatus Gerhardt, 1877, Hydaticus seminiger (De Geer, 1774), Laccobius minutus (Linnaeus, 1758); 2: Enochrus fuscipennis (Thomson, 1884), Laccophilus hyalinus (De Geer, 1774); 1: Corixa punctata Illiger, 1807, Gerris lacustris (Linnaeus, 1758), Graphoderus cinereus (Linnaeus, 1758), Graptodytes pictus (Fabricius, 1787), Helophorus brevipalpis Bedel, 1881, Helophorus redtenbacheri Kuwert, 1885, Hydrochara caraboides (Linnaeus, 1758), Hydrochara dichroma (Fairmaire, 1892), Hydrochus elongatus (Schaller, 1783), Hydroporus palustris (Linnaeus, 1761), Rhantus frontalis (Marsham, 1802), Sigara limitata (Fieber, 1848). 
Supplementary Table S2: The effect of phototaxis $(\mathrm{PH})$, polarotaxis $(\mathrm{PO})$ and their interaction (PP $=$ phototaxis + polarotaxis together) in species and assemblage level tested by two-way ANOVA and two-way non-parametric MANOVA analyses. Only species captured with at least 200 total numbers of individuals were tested. SS: sum of squares, MS: mean squares, F: MS (between, $\mathrm{PH}, \mathrm{PO}$ or PP) / $\mathrm{MS}$ (within or residual), $\mathrm{p}$ : significance value, $\mathrm{df}_{\mathrm{PH}}=1, \mathrm{df}_{\mathrm{PO}}=1, \mathrm{df}_{\mathrm{PP}}=1, \mathrm{df}_{\text {within/residual }}=56, \mathrm{df}_{\text {total }}=59$, $* * *$ : highly significant $(\mathrm{p}<0.01), * *$ : significant $(\mathrm{p}<0.05), *$ : marginally significant $(\mathrm{p}<0.1)$, $\mathrm{N}_{\text {total }}=$ total number of captured individuals including all treatments during the whole sampling period, indicating the commonness of the given species in our experiment. Relative numbers refers to hourly percentage distributions among the four treatments.

\begin{tabular}{|c|c|c|c|c|c|c|c|}
\hline Method & Taxa & $\begin{array}{l}\text { Source of } \\
\text { variance }\end{array}$ & \begin{tabular}{|c|} 
Variance \\
$\%$
\end{tabular} & SS & MS & $\mathbf{F}$ & $\mathbf{p}$ \\
\hline \multirow{10}{*}{$\begin{array}{l}\text { Two-way } \\
\text { ANOVA }\end{array}$} & \multicolumn{2}{|c|}{ Relative numbers $\mathbf{P H}$} & 20.9 & 11160 & 11160 & 29.16 & $1.404 \mathrm{E}-06 * * *$ \\
\hline & \multirow{4}{*}{$\begin{array}{l}\text { of captured } \\
\text { individuals } \\
\text { (without } \\
\text { Heterocerus } \\
\text { spp.) }\end{array}$} & PO & 34.6 & 18460 & 18460 & 48.23 & $4.264 \mathrm{E}-09 * * *$ \\
\hline & & $\mathbf{P P}$ & 4.4 & 2347 & 2347 & 6.133 & $0.01631 * *$ \\
\hline & & within & 40.1 & 21430 & 382.6 & & \\
\hline & & total & & 53390 & & & \\
\hline & \multicolumn{2}{|c|}{ Relative numbers $\mathbf{P H}$} & 36.6 & 22100 & 22100 & 76.93 & $4.235 \mathrm{E}-12 * * *$ \\
\hline & \multirow{4}{*}{$\begin{array}{l}\text { of captured } \\
\text { species (without } \\
\text { Heterocerus } \\
\text { spp.) }\end{array}$} & $\mathbf{P O}$ & 35.9 & 21650 & 21650 & 75.34 & $5.957 \mathrm{E}-12 * * *$ \\
\hline & & PP & 0.8 & 503.4 & 503.4 & 1.752 & 0.191 \\
\hline & & within & 26.7 & 16090 & 287.3 & & \\
\hline & & total & & 60340 & & & \\
\hline \multirow{5}{*}{$\begin{array}{l}\text { Two-way } \\
\text { non-parametric } \\
\text { MANOVA } \\
\text { (Bray-Curtis) }\end{array}$} & \multirow{5}{*}{$\begin{array}{l}\text { Assemblage } \\
\text { level }\end{array}$} & $\mathbf{P H}$ & 15.0 & 3.3641 & 3.3641 & 13.25 & $0.0001 * * *$ \\
\hline & & PO & 12.2 & 2.7495 & 2.7495 & 10.829 & $0.0001 * * *$ \\
\hline & & PP & 9.4 & 2.1078 & 2.1078 & 8.3014 & $0.0001 * * *$ \\
\hline & & residual & 63.4 & 14.219 & 0.2539 & & \\
\hline & & total & & 22.44 & & & \\
\hline \multirow{23}{*}{$\begin{array}{l}\text { Two-way } \\
\text { ANOVA }\end{array}$} & \multirow{5}{*}{$\begin{array}{l}\text { Sigara } \\
\text { falleni } \\
\mathrm{N}_{\text {total }}=23675\end{array}$} & $\mathbf{P H}$ & 28.2 & 16540 & 16540 & 51.29 & $1.869 \mathrm{E}-09 * * *$ \\
\hline & & PO & 32.1 & 18830 & 18830 & 58.41 & $3.001 \mathrm{E}-10 * * *$ \\
\hline & & $\mathbf{P P}$ & 8.9 & 5217 & 5217 & 16.18 & $0.0001742 * * *$ \\
\hline & & within & 30.8 & 18060 & 322.4 & & \\
\hline & & total & & 58640 & & & \\
\hline & \multirow{5}{*}{$\begin{array}{l}\text { Sigara } \\
\text { lateralis } \\
\mathrm{N}_{\text {total }}=5603\end{array}$} & $\mathbf{P H}$ & 8.6 & 5235 & 5235 & 7.913 & $0.006 * * *$ \\
\hline & & PO & 29.9 & 18140 & 18140 & 27.43 & $2.548 \mathrm{E}-06^{* * *}$ \\
\hline & & PP & 0.3 & 179.8 & 179.8 & 0.271 & 0.6042 \\
\hline & & within & 61.1 & 37050 & 661.6 & & \\
\hline & & total & & 60610 & & & \\
\hline & \multirow{5}{*}{$\begin{array}{l}\text { Heterocerus } \\
\text { spp. } \\
\mathrm{N}_{\text {total }}=4087\end{array}$} & $\mathbf{P H}$ & 45.7 & 34040 & 34040 & 47.98 & $4.567 \mathrm{E}-09 * * *$ \\
\hline & & PO & 0.7 & 484.2 & 484.2 & 0.6826 & 0.4122 \\
\hline & & $\mathbf{P P}$ & 0.2 & 172.5 & 172.5 & 0.2431 & 0.6239 \\
\hline & & within & 53.4 & 39720 & 709.3 & & \\
\hline & & total & & 74420 & & & \\
\hline & \multirow{5}{*}{$\begin{array}{l}\text { Berosus } \\
\text { frontifoveatus } \\
\mathrm{N}_{\text {total }}=2524\end{array}$} & $\mathbf{P H}$ & 23.9 & 13830 & 13830 & 35.26 & $1.914 \mathrm{E}-07 * * *$ \\
\hline & & PO & 31.9 & 18440 & 18440 & 47.01 & $5.9976 \mathrm{E}-09 * * *$ \\
\hline & & PP & 6.2 & 3572 & 3572 & 9.106 & $0.003829 * * *$ \\
\hline & & within & 38.0 & 21970 & 392.3 & & \\
\hline & & total & & 57820 & & & \\
\hline & \multirow{3}{*}{$\begin{array}{l}\text { Enochrus } \\
\text { quadripunctatus } \\
\mathrm{N}_{\text {total }}=2475\end{array}$} & $\mathbf{P H}$ & 20.6 & 10880 & 10880 & 21.54 & $0.00002132 * * *$ \\
\hline & & PO & 20.5 & 10830 & 10830 & 121.44 & $0.00002214 * * *$ \\
\hline & & $\mathbf{P P}$ & 5.4 & 2853 & 2853 & 5.651 & $0.02089 * *$ \\
\hline
\end{tabular}




\begin{tabular}{|c|c|c|c|c|c|c|}
\hline & within & 53.5 & 28280 & 504.9 & & \\
\hline & total & & 52830 & & & \\
\hline & $\mathbf{P H}$ & 40.7 & 24930 & 24930 & 50.51 & $2.301 \mathrm{E}-09 * * *$ \\
\hline Enochrus & PO & 10.8 & 6647 & 6647 & 13.47 & $0.0005426 * * *$ \\
\hline Bicolor & PP & 3.4 & 2095 & 2095 & 4.244 & $0.04404 * *$ \\
\hline $\mathrm{N}_{\text {total }}=1024$ & within & 45.1 & 27640 & 493.5 & & \\
\hline & total & & 61310 & & & \\
\hline & $\mathbf{P H}$ & 4.2 & 3428 & 3428 & 3.862 & $0.0543 *$ \\
\hline Hydroglyphus & PO & 31.9 & 26200 & 26200 & 29.53 & $1.242 \mathrm{E}-06^{* * *}$ \\
\hline geminus & PP & 3.4 & 2765 & 2765 & 3.116 & $0.0829 *$ \\
\hline $\mathrm{N}_{\text {total }}=873$ & within & 60.5 & 49700 & 887.4 & & \\
\hline & total & & 82090 & & & \\
\hline & $\mathbf{P H}$ & 18.9 & 11520 & 11520 & 14.01 & $0.0004313 * * *$ \\
\hline Cymbiodyta & PO & 4.9 & 2992 & 2992 & 3.638 & $0.0616^{*}$ \\
\hline marginella & $\mathbf{P P}$ & 0.6 & 350 & 350 & 0.4255 & 0.5169 \\
\hline $\mathrm{N}_{\text {total }}=809$ & within & 75.6 & 46060 & 822.5 & & \\
\hline & total & & 60920 & & & \\
\hline & $\mathbf{P H}$ & 3.2 & 1750 & 1750 & 2.593 & 0.113 \\
\hline Helochares & PO & 27.2 & 14840 & 14840 & 21.99 & $0.00001798 * * *$ \\
\hline obscurus & $\mathbf{P P}$ & 0.2 & 96.34 & 96.34 & 0.1428 & 0.707 \\
\hline $\mathrm{N}_{\text {total }}=781$ & within & 69.4 & 37790 & 674.8 & & \\
\hline & total & & 54480 & & & \\
\hline & $\mathbf{P H}$ & 1.4 & 840 & 840 & 14.01 & $0.0004 * * *$ \\
\hline Sigara & PO & 22.7 & 13860 & 13860 & 22.91 & $0.0000128 * * *$ \\
\hline striata & $\mathbf{P P}$ & 7.6 & 4600 & 4600 & 7.61 & $0.0078 * * *$ \\
\hline $\mathrm{N}_{\text {total }}=709$ & within & 55.7 & 33890 & 605.1 & & \\
\hline & total & & 60830 & & & \\
\hline & $\mathbf{P H}$ & 35.1 & 20910 & 20910 & 43.08 & $1.817 \mathrm{E}-08 * * *$ \\
\hline Berosus & PO & 15.5 & 9196 & 9196 & 18.94 & $0.00005772 * * *$ \\
\hline spinosus & PP & 3.7 & 2193 & 2193 & 4.523 & $0.0378^{* *}$ \\
\hline $\mathrm{N}_{\text {total }}=511$ & within & 45.7 & 27190 & 485.4 & & \\
\hline & total & & 59490 & & & \\
\hline & $\mathbf{P H}$ & 40.8 & 35020 & 35020 & 283.9 & $1.368 \mathrm{E}-23 * * *$ \\
\hline Hydrobius & PO & 26.7 & 22930 & 22930 & 185.9 & $1.948 \mathrm{E}-19 * * *$ \\
\hline fuscipes & $\mathbf{P P}$ & 24.5 & 21000 & 21000 & 170.2 & $1.28 \mathrm{E}-18 * * *$ \\
\hline $\mathrm{N}_{\text {total }}=484$ & within & 8.0 & 6908 & 123.4 & & \\
\hline & total & & 85860 & & & \\
\hline & PH & 0.2 & 148.4 & 148.4 & 0.125 & 0.725 \\
\hline Hygrotus & PO & 22.0 & 19320 & 19320 & 16.28 & $0.0001676^{* * *}$ \\
\hline inaequalis & PP & 2.1 & 1805 & 1805 & 1.521 & 0.2227 \\
\hline $\mathrm{N}_{\text {total }}=318$ & within & 75.8 & 66460 & 1187 & & \\
\hline & total & & 87730 & & & \\
\hline & $\mathbf{P H}$ & 15.1 & 10770 & 10770 & 15.16 & $0.0002 * * *$ \\
\hline Hesperocorixa & PO & 21.6 & 15440 & 15440 & 21.74 & $0.00001977 * * *$ \\
\hline linnaei & PP & 7.5 & 5344 & 5344 & 7.525 & $0.0081 * * *$ \\
\hline $\mathrm{N}_{\text {total }}=253$ & within & 55.8 & 39770 & 710.3 & & \\
\hline & total & & 71330 & & & \\
\hline
\end{tabular}

